\begin{tabular}{c|c|c}
\hline \hline & CLIMATE RESEARCH \\
Vol. 17: 83-92, 2001 & Clim Res & Published July 4 \\
\hline
\end{tabular}

\title{
Intra-seasonal convective structure and evolution over tropical East Africa
}

\author{
Emmanuel J. Mpeta*, Mark R. Jury \\ Environmental Studies Dept. University of Zululand, KwaDlangezwa 3886, South Africa
}

\begin{abstract}
Intra-seasonal convection oscillations over southwestern Tanzania during the December to February season are examined using 15 yr (1979 to 1994) of pentad Outgoing Longwave Radiation (OLR) data and kinematic/thermodynamic parameters from ECMWF data. Most significant spectral energy for an area-averaged OLR index is concentrated in periods of 16 to $33 \mathrm{~d}$. Time-longitude diagrams of filtered OLR, and zonal wind anomalies at $850 \mathrm{hPa}$ averaged over the 7.5 to $10^{\circ} \mathrm{S}$ latitude band for the period November to May reveal eastward (62\%), westward (11\%) and quasi-stationary convective $(27 \%)$ features. Phase speeds for transient cases are in the range of 2 to $8 \mathrm{~m} \mathrm{~s}^{-1}$. In the eastward propagating case study, 1 to 15 January 1993, map sequences reveal that deep convection shifts northeastward as a southern mid-latitude trough couples with the ITCZ. Convective events over tropical east Africa are associated with an influx of northeasterly Indian monsoon flow followed by increased westerlies from the Guinea/Congo region. Eastward propagating OLR anomalies couple with zonal circulations, suggesting that a transient Walker cell emerges periodically from East Africa.
\end{abstract}

KEY WORDS: Intra-seasonal climate · East Africa

Resale or republication not permitted without written consent of the publisher

\section{INTRODUCTION}

The economies of tropical East Africa depend on climate for food, water and hydropower. Our focus here is on Tanzania, a country in East Africa of 34 million people occupying the area 0 to $10^{\circ} \mathrm{S}, 30$ to $40^{\circ} \mathrm{E}$. Per capita GDP (gross domestic product) is $\$ 210 \mathrm{yr}^{-1}$, placing it amongst the poorest nations of the world, but improved governance has resulted in an annual growth rate of $+3 \%$ over the past decade. About half of the current GDP is attributable to agriculture, mainly in the form of maize production, which is plagued by intermittent rains. Exports include coffee $(\$ 117 \mathrm{M})$ and cotton $(\$ 115 \mathrm{M})$, both of which are reliant on rainfall. Recently, in 1996 and 1998 to 2000, much of tropical east Africa has endured repeated drought conditions related to La Niña conditions. The droughts led to a collapse of subsistence crop production and food aid

${ }^{*}$ Permanent affiliation: Tanzanian Directorate of Meteorology, Dar es Salaam, Tanzania.

E-mail: mjury@pan.uzulu.ac.za was needed. During the 1997 El Niño, economic growth declined as widespread floods occurred. By improving knowledge on climate-weather interactions, it is hoped that actions can be taken to mitigate the risk and economic consequences caused by climate in these countries.

Food resources depend on intermittent wet spells to replenish soils desiccated by long hot dry seasons. For proper agricultural planning and management of water resources, an understanding of rainfall variability at relevant time scales is required. A number of studies have addressed rainfall variability at daily and annual scales, but little work has been done at the intra-seasonal time scale. In order to lay a foundation for the monitoring and prediction of intra-seasonal rainfall, an understanding of kinematic and thermodynamic processes associated with the oscillation is required.

Utilization of climatological information and prediction in the planning of farming effort is becoming popular in Tanzania. It is common to come across a farmer asking when there will be a dry spell within the rainy 
season to allow for the spraying of pesticides or application of fertilizer. The study of intra-seasonal rainfall variability is most appropriate in this regard.

Intra-Seasonal Oscillations (ISO) in the atmosphere are generally defined as fluctuations with periods longer than a week but shorter than a season (Makarau 1994). Madden \& Julian (1971) discovered a 40 to $50 \mathrm{~d}$ oscillation in the equatorial region. In their pioneering work they described the oscillations as a global-scale eastward-propagating zonal circulation cell along the equator. These low frequency oscillations have been studied by many researchers, including Wang \& Rui (1990), Murakami \& Nakazawa (1985), Lau \& Peng (1987), Weickmann \& Khalsa (1990), Vincent et al. (1991) and others. Knutson \& Weickmann (1987) noted a large-scale (wave number one) tropical divergent wind feature propagating eastward around the globe throughout the seasonal cycle. They found that there was good agreement between areas of upper-air divergence and areas of convection inferred from the Outgoing Longwave Radiation (OLR) satellite data. Convection anomalies are smaller over tropical Africa and South America than over the Indian and Western Pacific oceans. Coherent waves exhibited by OLR anomalies are weaker over cooler tropical surfaces. Eastward-propagating large-scale circulation features on a 30 to $60 \mathrm{~d}$ time scale have been documented by Lorenc (1984) and Krishnamurti et al. (1985), who studied velocity potential for the FGGE (first Global GARP Experiment) year. Madden \& Julian (1972), Madden (1986), Hendon \& Liebman (1990) and others have noted similar propagation characteristics for tropical zonal wind anomalies. Some key observational features of the inter-seasonal variability of the tropical atmosphere are synthesized in Lau \& Peng (1987).

A few theories have so far been proposed to explain the underlying physical mechanism for the excitation, maintenance and propagation of tropical low frequency intra-seasonal waves. Chang (1977) suggested that the eastward-propagating intra-seasonal oscillation is a manifestation of convectively driven equatorially trapped Kelvin waves resulting from an interaction between the equatorial dynamics and tropical convection.

The aim of this paper is to characterise intra-seasonal oscillations over tropical east Africa and to elucidate the kinematic and thermodynamic processes responsible for generating dry and wet spells in the December to February rainy season. The main objectives of the study are to: (1) Identify and describe the nature of convective variability over southwestern Tanzania during the summer season. (2) Identify propagating convective systems with associated circulation systems. (3) Identify kinematic and thermodynamic fea- tures associated with precursor and convection phases in the horizontal and vertical plane.

In the next section data and methods used in the study are briefly discussed. In Section 3 we provide Hovmoller results of OLR and zonal wind anomalies, and discuss map sequences for composite and case study intra-seasonal convective events via kinematic and thermodynamic parameters. This helps to understand how these events evolve over time. The summary and conclusions are presented in Section 4.

\section{DATA AND METHODOLOGY}

2.1. Data. This study focuses on tropical East Africa and its surrounds, $15^{\circ} \mathrm{N}$ to $35^{\circ} \mathrm{S}$ and 0 to $100^{\circ} \mathrm{E}$. The variability of convection is studied using satellite OLR data from the National Centre for Environmental Prediction (NCEP); and ECMWF model data for 12 UT winds at 850 and $200 \mathrm{hPa}, 500 \mathrm{hPa}$ equivalent potential temperature, and water vapour flux. All data are available at $2.5^{\circ}$ resolution for the period 1979 to 1994 .

2.2. Methodology. To investigate intra-seasonal convective oscillations over southwestern (SW) Tanzania, an index was created by areal averaging of pentad OLR values. Comparisons were made for a wider area from 0 to $10^{\circ} \mathrm{S}, 30$ to $40^{\circ} \mathrm{E}$ and a smaller area from 7.5 to $10^{\circ} \mathrm{S}$ and 30 to $35^{\circ} \mathrm{E}$. Nearly identical results were achieved. Fig. 1 shows the time series plot of the $10 \times$ $10^{\circ}$ anomaly index from 1979 to 1994 . Values were obtained by subtracting the historical mean annual cycle. Spectral analysis was applied to the series to explore cyclical behaviour. Longitude-time (Hovmoller) plots were used to identify zonally propagating features over the latitude belt 7.5 to $10^{\circ} \mathrm{S}$. A detailed description of the methodologies can be found in Mpeta (1997). A Fast Fourier Transform (FFT) smoother was applied to suppress high frequency (5 to $15 \mathrm{~d}$ ) oscillations in Hovmoller analyses.

From the OLR index time series plots for each season, cases were selected for inclusion into an overall intra-seasonal composite. Our focus is on the most intense convective cases and their precursors. Deep convective pentads (P0) were selected when OLR index values were $<190 \mathrm{~W} \mathrm{~m}^{-2}$ over SW Tanzania in the DJF season. Precursor pentads were chosen when OLR index values were 210 to $240 \mathrm{~W} \mathrm{~m}^{-2}$ and occurring just before the convective event. Using these criteria 13 cases were obtained in the period 1979 to 1994. Mean composite maps for deep convection and onset phases were formulated by adding together the selected fields, dividing by the sample and subtracting the seasonal mean. Composite anomalies are useful to indicate common features, trends and patterns in the meteorological fields, particularly in tropical regions 


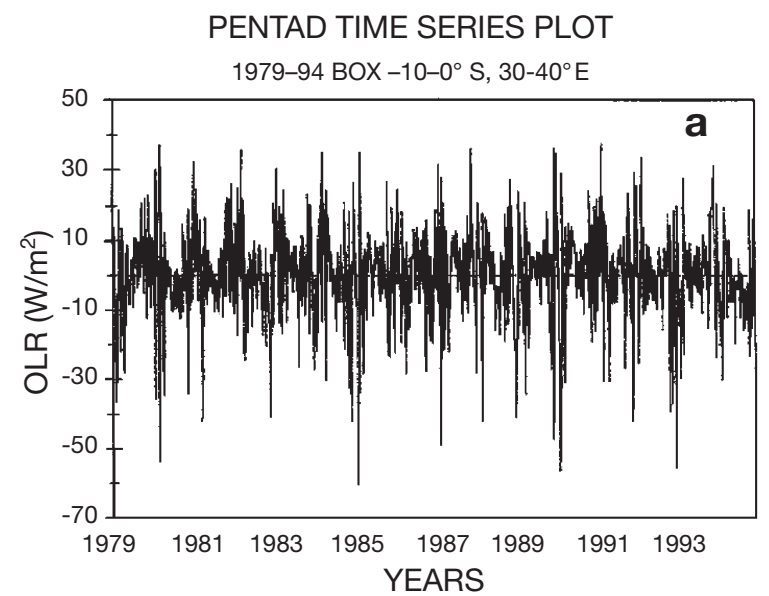

SPECTRUM OF PENTAD OLR INDEX (BOX $\left.30-40^{\circ} \mathrm{E}, 0-10^{\circ} \mathrm{S}\right)$

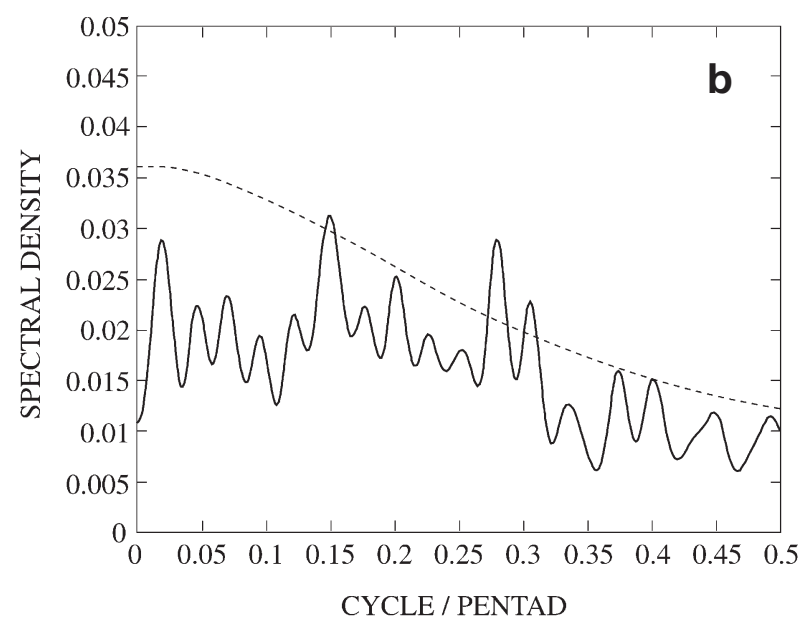

Fig. 1. (a) Time series of continuous pentad OLR (Outgoing Longwave Radiation) anomaly averaged over Tanzania 1979 to 1994; (b) spectral density plot showing dominant frequencies at 33 and 18 to 16 d (95\% confidence interval is given)

where temperature differences are weak (Asnani 1993). In addition a case study eastward moving convective system in January 1993 was analysed.

\section{RESULTS}

\subsection{Convection oscillations}

Tropical convection is often modulated by zonal moving waves. There are 2 types: those moving from the east of short wavelength (easterly waves) and slower oscillations from the west (Madden-Julian Oscillation, MJO). Spectral results for the continuous OLR series (Fig. 1) reveal significant cycles in the range of 16 to $18 \mathrm{~d}$ with a weaker harmonic at $33 \mathrm{~d}$. The potential for transient wave activity is seasonally modulated by the position and intensity of the ITCZ, which is furthest south and most intense during mid-summer: December-January-February. However it is unclear to what extent convection associated with the ITCZ over east Africa is pulsed intra-seasonally (Mutai \& Ward 1998); hence kinematic and thermodynamic features from time series, Hovmoller and map sequences are analysed.

Area-averaged pentad OLR DJF time series for various years reveal a variable character (Fig. 2). Extreme ranges of pentad OLR are $274 \mathrm{~W} \mathrm{~m}^{-2}$ (1993) to $154 \mathrm{~W}$ $\mathrm{m}^{-2}$ (1984). Three to four deep convective events occur each summer $\left(\mathrm{OLR}<210 \mathrm{~W} \mathrm{~m}^{-2}\right)$. Some years exhibit shorter periods (e.g. 1982/83 and 1990/91) while others show lower frequency variability (e.g. 1987/88) or mixed cycles. The average cycle period was found to be about $20 \mathrm{~d}$, with peaks ranging from 15 to $55 \mathrm{~d}$. As pointed out by Madden (1994), Weickmann et al. (1985), Vincent et al. (1991), and Murakami et al. (1986) the intra-seasonal oscillation has a broad spectral character. Subdividing the cycle periods into $>10$, $>20$ and >30 d for the summers of 1979 to 1994, spectral peaks of 10 to $20 \mathrm{~d}$ period occurred $21 \%$ of the time, intermediate periods occurred $33 \%$ of the time, and $>30 \mathrm{~d}$ (the MJO) were most prevalent at $46 \%$, as summarised in Table 1.

\subsection{Hovmoller analysis of system propagation}

Characteristics of zonally propagating convective systems can be analysed using Hovmoller or longitude-time analysis of OLR anomalies. These reveal a multitude of propagating and quasi-stationary systems. Eastward-moving systems dominate two-thirds

Table 1. Periods of dominant spectral energy, *low frequency peak

\begin{tabular}{|lccc|}
\hline Years & $\begin{array}{c}2 \leq \mathrm{P} \geq 4 \\
\text { Pentads }\end{array}$ & $\begin{array}{c}4 \leq \mathrm{P} \geq 6 \\
\text { Pentads }\end{array}$ & $\begin{array}{c}\mathrm{P}>6 \\
\text { Pentads }\end{array}$ \\
\hline $1981 / 82$ & & 4.57 & $10.67^{*}$ \\
$1982 / 83$ & & 4.57 & \\
$1983 / 84$ & & 4.57 & 8 \\
$1984 / 85$ & 2.67 & 5.33 & $10.67^{*}$ \\
& 2 & & \\
$1985 / 86$ & 2.46 & 4 & 6.4 \\
$1986 / 87$ & 3.2 & 4 & 6.4 \\
$1987 / 88$ & & & 8 \\
$1988 / 89$ & & & $10.67^{*}$ \\
$1989 / 90$ & & 4.57 & $10.67^{*}$ \\
$1990 / 91$ & 3.2 & 5.33 & 6.4 \\
$1991 / 92$ & & $33 \%$ & $46 \%$ \\
$1992 / 93$ & $21 \%$ & & \\
$1993 / 94$ & & & \\
Percentage & & & \\
& & & \\
\hline
\end{tabular}



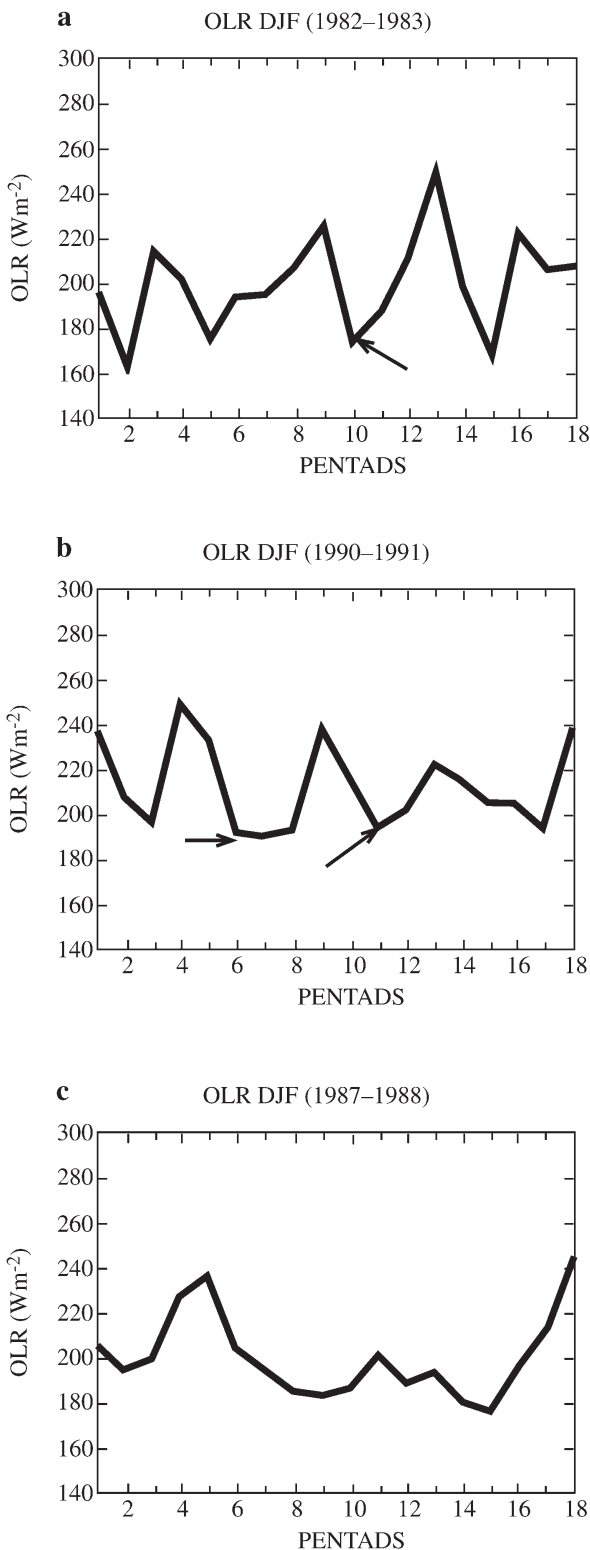

Fig. 2. Time series of the area-averaged OLR index for SW Tanzania; examples for 1982-83, 1990-91, and 1987-88 are given. Arrows refer to cases selected for inclusion into the composite analysis

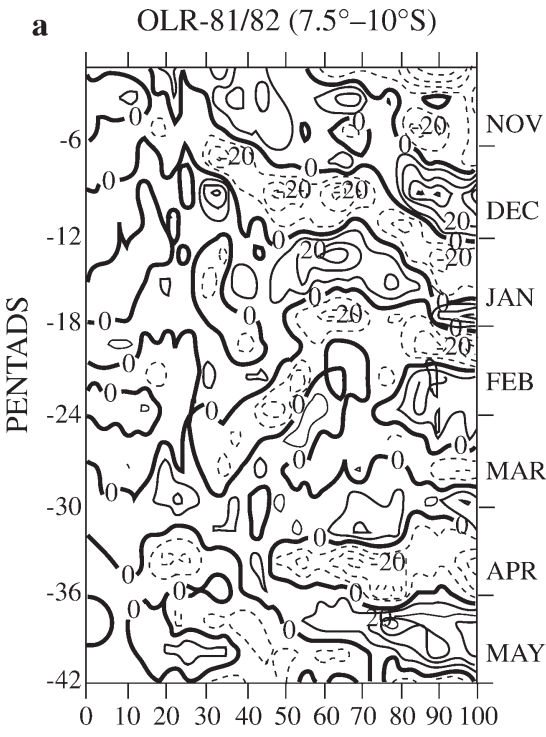

LONGITUDE

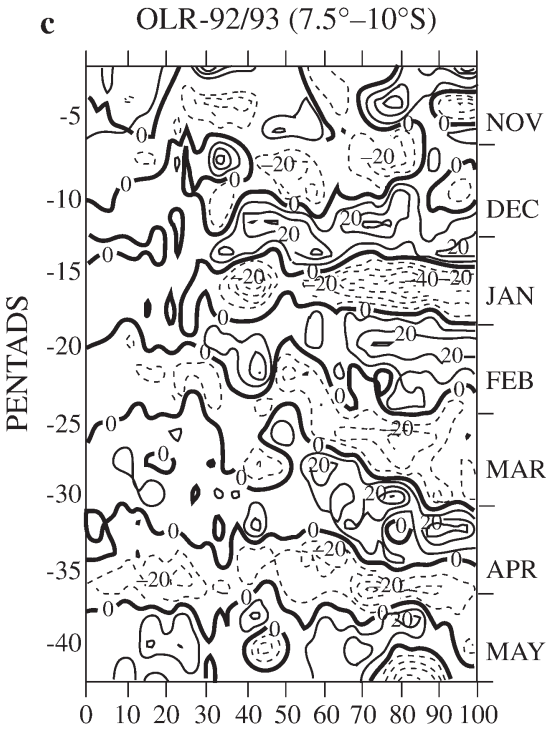

LONGITUDE

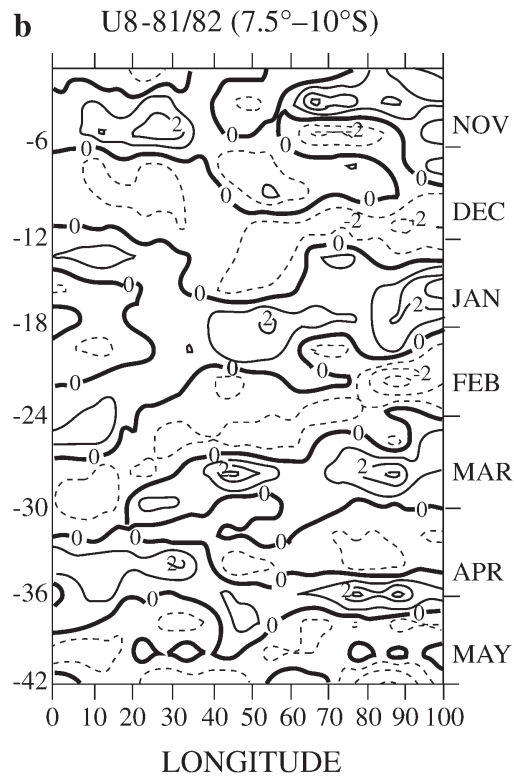

d $\quad \operatorname{U} 8-92 / 93\left(7.5^{\circ}-10^{\circ} \mathrm{S}\right)$

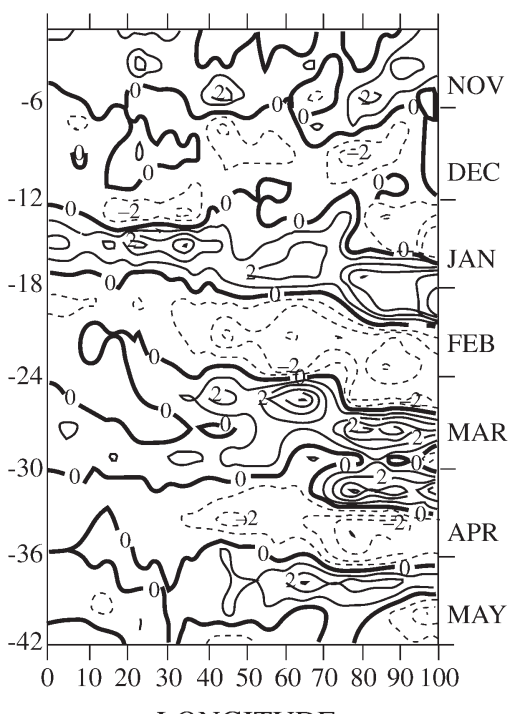

LONGITUDE

Fig. 3. Time-longitude Hovmoller plots of OLR and $850 \mathrm{hPa}$ wind anomalies averaged over the 7.5 to $10^{\circ} \mathrm{S}$ band. Intervals are contoured at $10 \mathrm{~W} \mathrm{~m}^{-2}$ and $2 \mathrm{~m} \mathrm{~s}^{-1}$ respectively; dashed lines refer to negative values (e.g. more convective and easterly winds)

of the time, quasi-stationary about one-quarter, and westward the remainder. In the following section we provide a qualitative description of these systems.

Hovmoller analysis of OLR anomalies for the period 1979 to 1994 reveals prevailing eastward-propagating anomalies (Fig. 3). It has been found that large negative anomaly values $\left(<-40 \mathrm{~W} \mathrm{~m}^{-2}\right)$ remain east of $40^{\circ} \mathrm{E}$. To the west, over Africa, the amplitude is weaker. It is thought that meridional circulations around the African highlands may inhibit growth and propagation of MJO from the Atlantic. In contrast, pulsed convection within the ITCZ is more common over the Indian Ocean, as found by Rui \& Wang (1990). This is true for both eastward-propagating and quasi-stationary systems. Eastward-propagating features are found to occur in most years. Westward-propagating features are found in January 1981 to March 1982, and April 1983 to May 1983. On a few occasions, propagating convective systems originate over the tropical Atlantic and continue east beyond $100^{\circ} \mathrm{E}$, while others origi- 
Fig. 4. Composite map sequence for P-1 precursor and P0 convective phases illustrating composite OLR anomalies averaged over 13 cases. Dashed lines refer to convective winds; contour interval is $5 \mathrm{~W} \mathrm{~m}^{-2}$
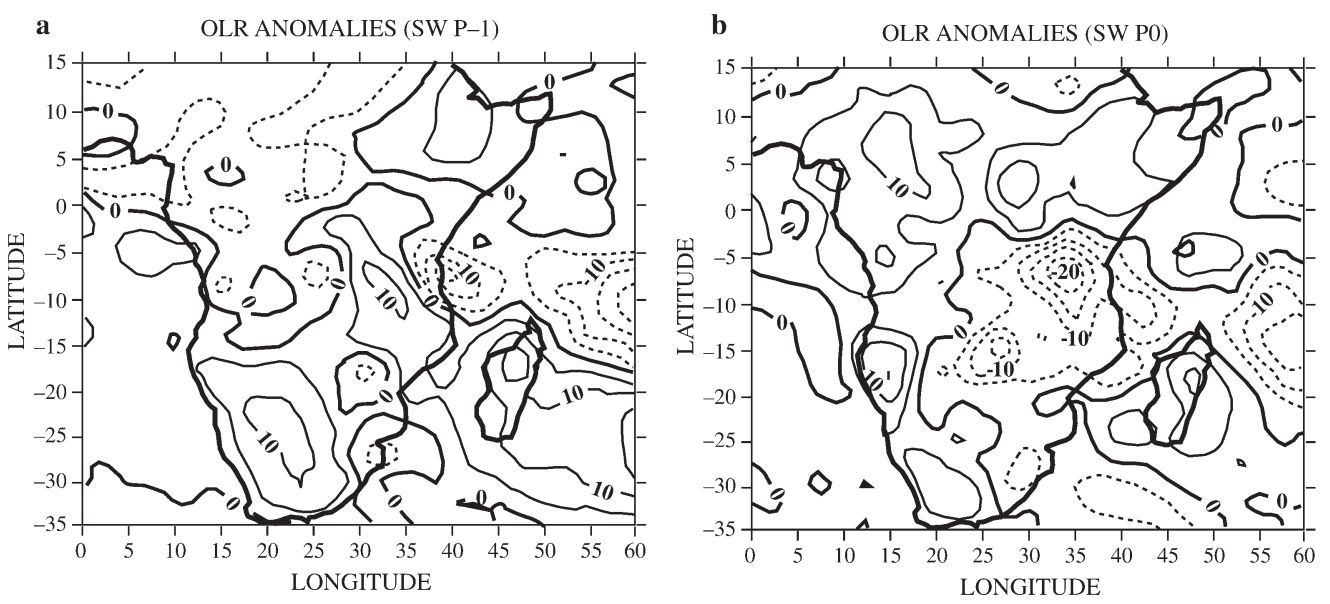

nate over east Africa and continue past Indonesia, in agreement with Levey (1993). Eastward-propagating systems exhibit a phase speed of 2 to $8 \mathrm{~m} \mathrm{~s}^{-1}$.

Hovmoller analysis of filtered zonal wind anomalies at $850 \mathrm{hPa}$ level averaged over the latitude band $7.5^{\circ}$ to $10^{\circ} \mathrm{S}$ (Fig. 3) corroborate features seen in the OLR anomalies. Eastward propagating systems are revealed in most years while westward-propagating features are indicated in some years. The period of the oscillation, estimated by averaging the length of time taken for the OLR anomaly to change sign within the 30 to $35^{\circ} \mathrm{S}$ longitude band, was found to be 30 to $50 \mathrm{~d}$. U-component anomalies $>4 \mathrm{~m} \mathrm{~s}^{-1}$ with well-defined patterns are revealed east of $40^{\circ} \mathrm{E}$. The elevated land surface and low level meridional monsoon flow may interfere with propagation across Africa. It has been found that areas of strong convection lie just downstream of westerly low level wind anomalies (Rui \& Wang 1990, Knutson \& Weickmann 1987 and others). Fig. 3 gives examples of Hovmoller plots for 1981/82 and 1992/93 for filtered OLR and zonal wind component anomalies in the 7.5 to $10.0^{\circ} \mathrm{S}$ latitude band. In
Fig. 3a an eastward-propagating case can be seen, and this is analysed in detail in Section 3.4.

\subsection{Composite map sequence}

Identifying a mean convective event, we composite a group of 13 cases for analysis here. The evolution of composite pentad convective anomaly patterns is illustrated in Fig. 4. At pentad P-1 positive OLR anomalies, indicating subsident conditions, are located over SW Africa, the SW Indian Ocean and Madagascar. Negative OLR anomalies (rainy conditions) are located off the coast of Tanzania and the western Indian Ocean. At P0 negative OLR anomalies occur over SW Tanzania and its surrounds. Convection is simultaneously inhibited over central Africa along $5^{\circ} \mathrm{N}$.

With sufficient moisture in the atmosphere, wind convergence at low levels and divergence at upper levels can trigger and sustain convection (Steiner 1989, Chen \& Tzeng 1990). The composite water vapour flux (WVF) patterns in Fig. 5 show an anticyclonic anomaly
Fig. 5. Composite map sequence (as in Fig. 4) for water vapour flux anomalies integrated from surface to $500 \mathrm{hPa}$. Length of arrow indicates amplitude according to key ( $\mathrm{kg}$ $\mathrm{m}^{-1} \mathrm{~s}^{-1}$ )
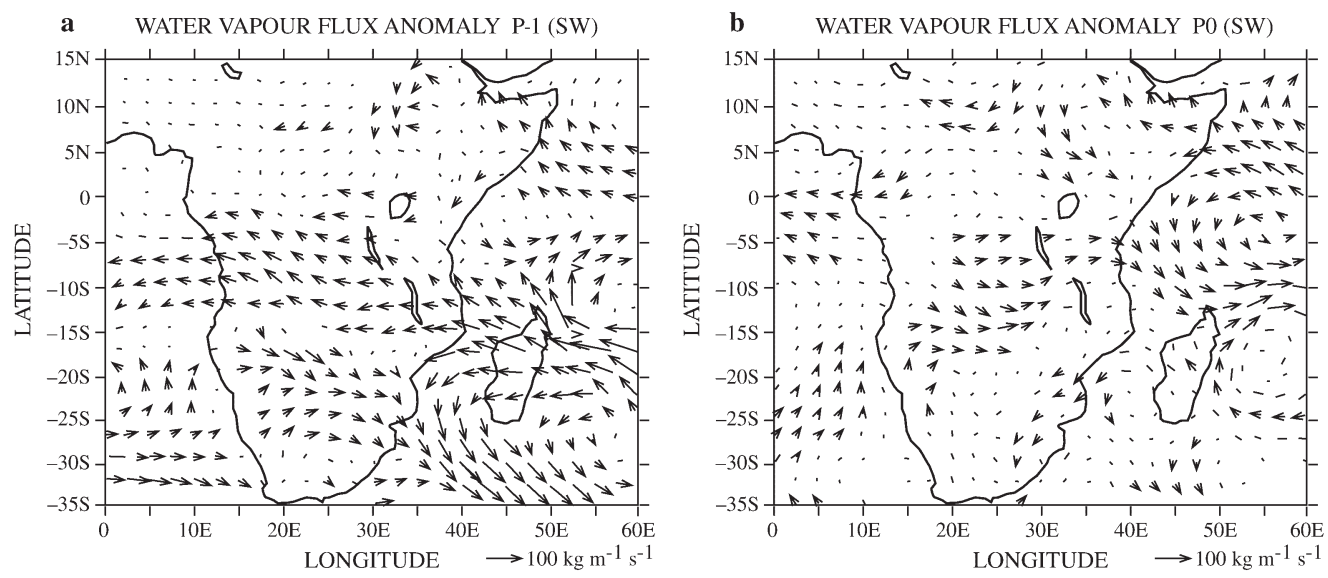

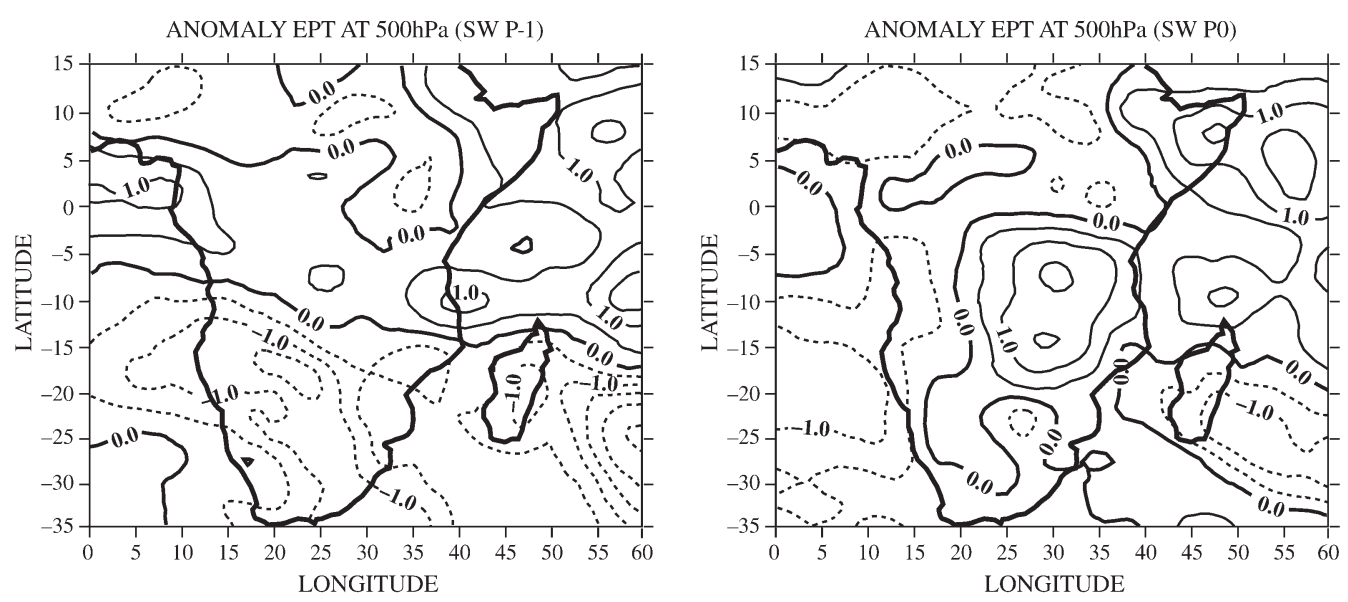

Fig. 6. Composite map sequence (as in Fig. 4) for equivalent potential temperature (EPT) anomalies at $500 \mathrm{hPa}$. Interval $0.5^{\circ} \mathrm{C}$, positive values refer to latent heating of the midtroposphere

over the SW Indian Ocean. Water vapour is advected from Madagascar across east Africa in the 5 to $15^{\circ} \mathrm{S}$ latitude band. Flow over southern Africa represents a cyclonic trough intruding from higher latitudes. The influx of moisture from the Indian Ocean is critical for convection, regardless of how much incoming water vapour recurves in the Mozambique Channel during the precursor phase. During the convective phase, the WVF reverses and becomes westerly across the 5 to $15^{\circ} \mathrm{S}$ latitude band. This induces convective activity over tropical east Africa.

Mid-tropospheric equivalent potential temperature (EPT) can be used to monitor latent heating in convection obtained from the rapid lifting of tropical moisture.
Fig. 6 illustrates the composite EPT anomaly fields at 500 hPa at P-1 and P0. Negative EPT anomaly values are noted south of $10^{\circ} \mathrm{S}$, whilst positive EPT anomalies occur over the west Indian Ocean and across Africa from 0 to $5^{\circ} \mathrm{S}$. At P0, negative EPT anomalies are located over the Atlantic Ocean south of $7.5^{\circ} \mathrm{S}$ and east of Madagascar. More significantly, positive EPT anomalies are found over east Africa from 5 to $15^{\circ} \mathrm{S}, 25$ to $40^{\circ} \mathrm{E}$ and over the west Indian Ocean north of $15^{\circ} \mathrm{S}$. This indicates a warming of the mid-troposphere brought about by the release of latent heat in cloud development during convection.

The east-west vertical cross-section of composite zonal wind anomalies is presented in Fig. 7, which shows that composite easterlies dominate the mid-

\section{U-COMP. ANOMALY ALONG 7.5 $\mathrm{S}(\mathrm{P}-1)$}

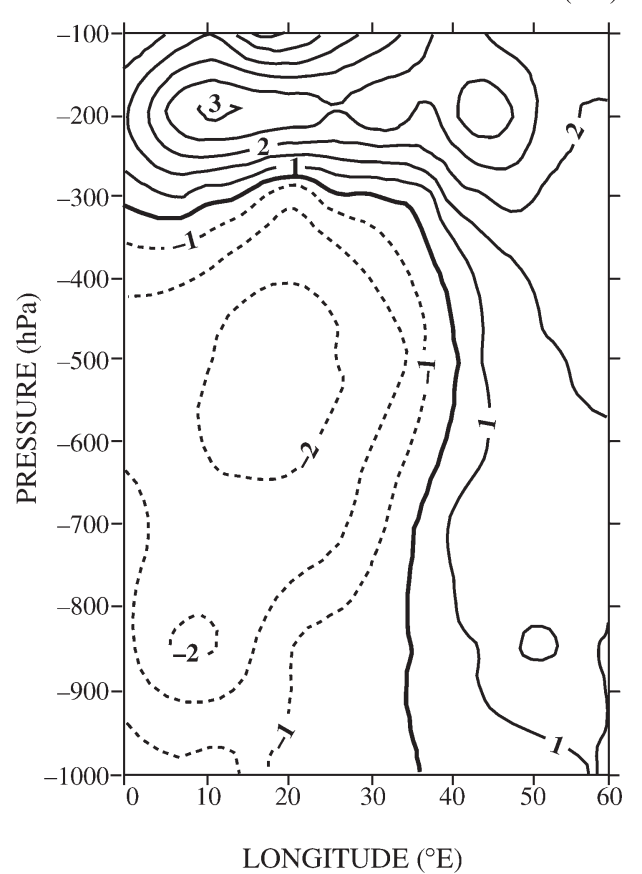

U-COMP. ANOMALY ALONG 7.5 S (P0)

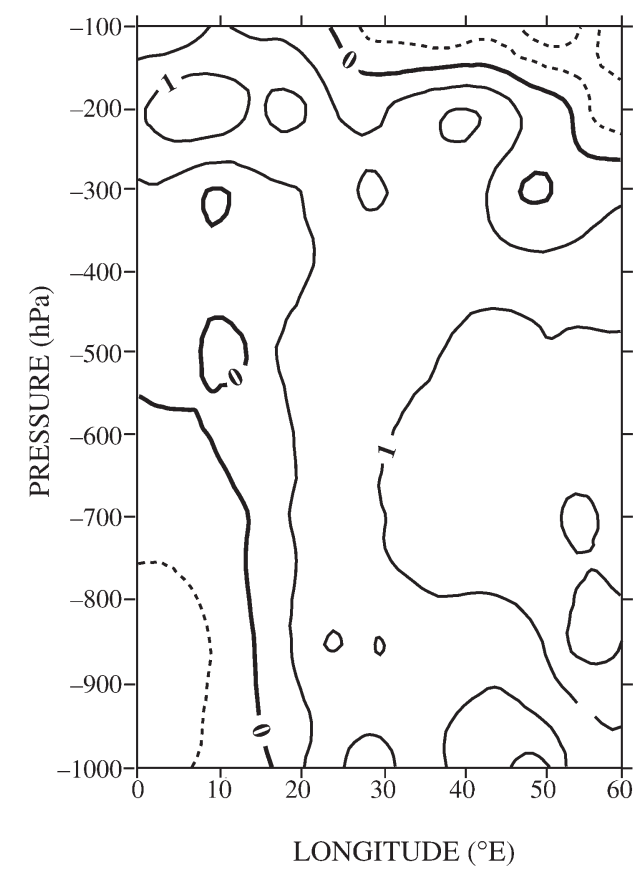

Fig. 7. Composite vertical section of zonal wind anomalies along $7.5^{\circ} \mathrm{S}$ for $\mathrm{P}-1$ and $\mathrm{P} 0$ phases. Dashed lines refer to easterlies; interval $0.5 \mathrm{~m} \mathrm{~s}^{-1}$ 

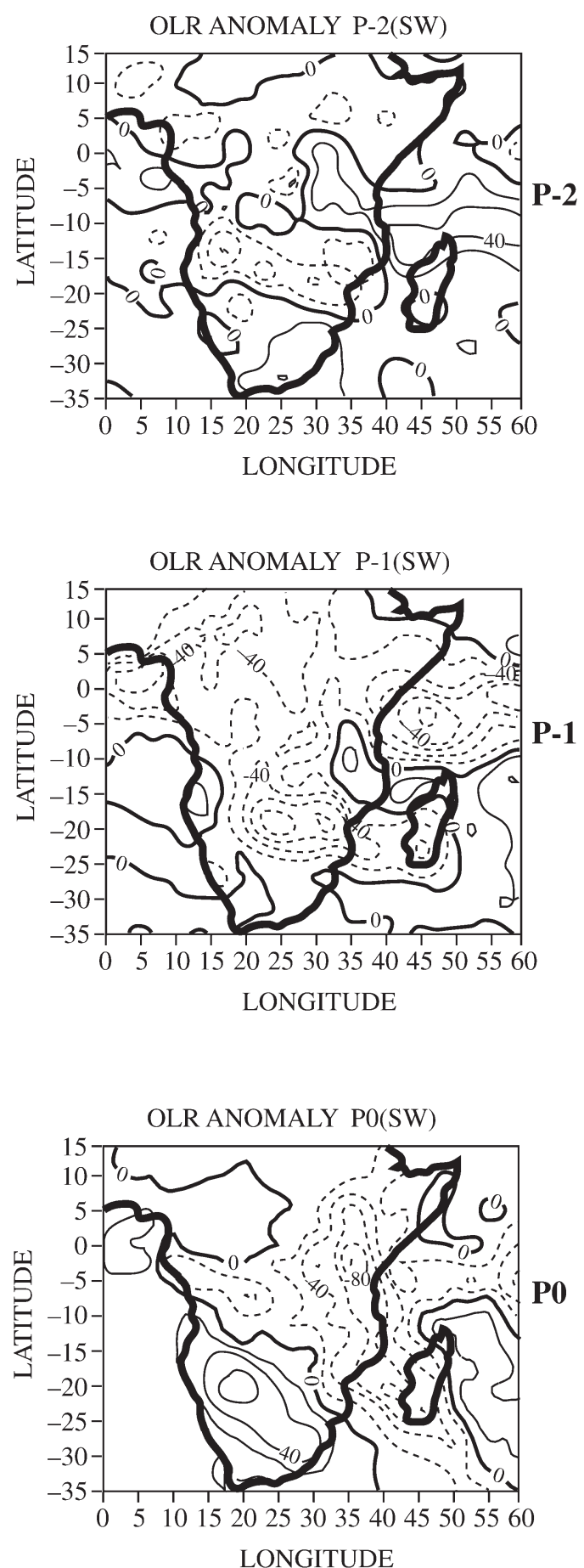

Fig. 8. Case study map sequence for P-2, P-1 and P0 phases illustrating OLR anomalies for pentads in early January 1993. Dashed lines refer to convective winds; contour interval is $20 \mathrm{~W} \mathrm{~m}^{-2}$

levels over Africa at P-1. In the upper levels and over the Indian Ocean, westerly anomalies are prevalent. Together, the lower level zonal flow is divergent $(+\partial u / \partial x)$ over east Africa and suppresses convection in the precursor phase. During the convective event (P0) the flow becomes anomalously westerly everywhere east of $20^{\circ} \mathrm{E}$. This 'push-pull' circulation indicates that the influx of Indian Ocean air is followed by the intrusion of Guinea/Congo air, a pattern related to passage of MJO and similar to that found by Mutai \& Ward (1998).

\subsection{Case study 1993: Map sequence analysis}

In this section the kinematic and thermodynamic fields associated with an eastward-moving convective system in 1993 are studied and the evolution is analysed for 3 pentad phases using OLR anomalies, WVF and wind at $200 \mathrm{hPa}$. The spatial evolution of OLR phases from January 1 to 15, 1993, for the eastward-propagating case is shown in Fig. 8. At P-2 negative OLR anomalies are located over the continent between 10 and $20^{\circ} \mathrm{S}$ and positive anomalies are found over Tanzania. At P-1 large negative OLR anomalies are shown off the coast of Tanzania and between 10 and $20^{\circ} \mathrm{S}$. A steady eastward push of negative OLR anomalies is indicated from pentad P-2 to P0 as positive anomalies develop over SW Africa.

The map sequence of WVF (Fig. 9) indicates that moisture supply is mainly from the northeasterly monsoon of the Arabian Sea. Some confluence is noted over the continent along $17^{\circ} \mathrm{S}$ and Madagascar. At P-1 a northwest-southeast convergence zone is observed over SW Africa. By P0 this feature shifts eastward across Africa, producing confluence from the Gulf of Guinea to Madagascar. Westerly wind flow pushes in behind the trough from 0 to $10^{\circ} \mathrm{S}$.

Time evolution of winds at $200 \mathrm{hPa}$ level for the January 1993 case study is presented in Fig. 10. Diffluent flow is located over the Congo basin at both P-2 and $\mathrm{P}-1$. Relatively stronger easterly winds are located over the coast of Angola and Zaire. Cyclonic flow over NW Tanzania may be associated with mountain waves as suggested by Semazzi (1980). Cross-equatorial southeasterly flow is dominant at P0. The steady eastward shift of an anticyclone/trough system in the southern hemisphere is noted from P-2 to P0. This is accompanied by expansion of southeasterly winds in the tropics.

\section{SUMMARY AND CONCLUSIONS}

The pattern and evolution of intra-seasonal rainfall in east Africa and its teleconnections with the regional circulation has been studied. Our empirical analysis sought to identify kinematic and thermodynamic features associated with intra-seasonal convective vari- 
WATER VAPOUR FLUX FIELD P-2 (SW)

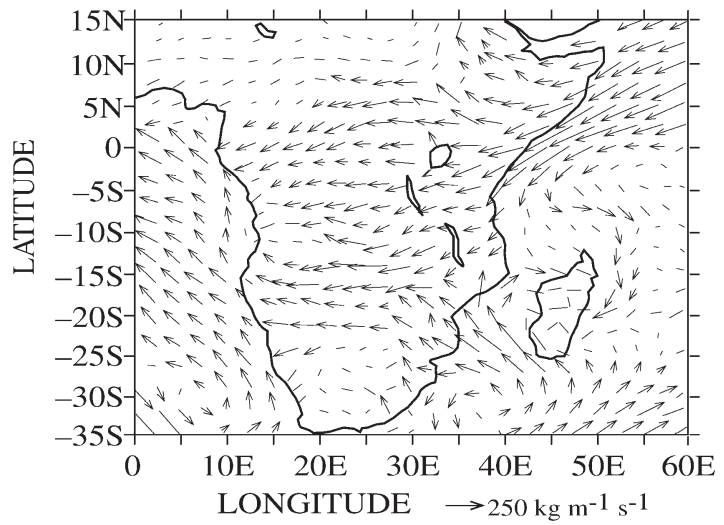

WATER VAPOUR FLUX FIELD P-1 (SW)

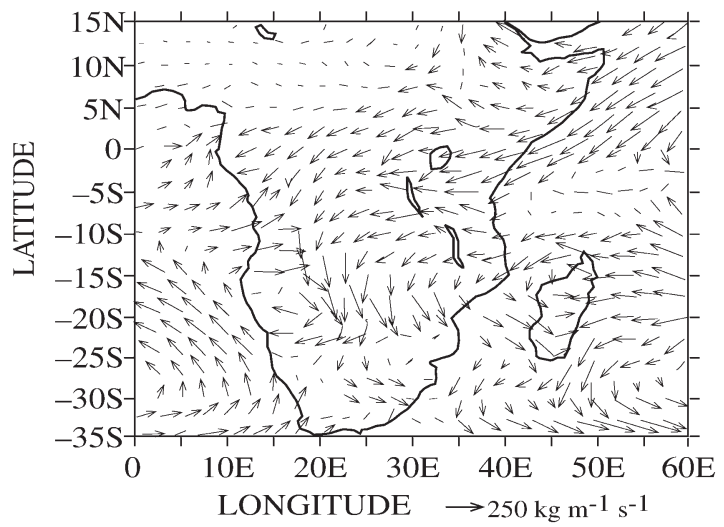

WATER VAPOUR FLUX FIELD PO (SW)

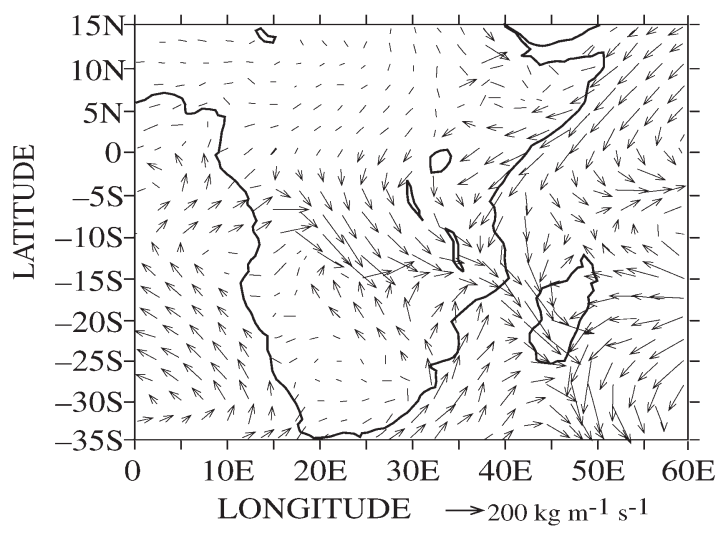

Fig. 9. Case study map sequence (as in Fig. 8) for water vapour flux. Length of arrow indicates amplitude according to key

ability using pentad OLR and ECMWF data. Time series plots and spectral analyses were performed on the pentad OLR index to determine convective variability and periodicities at an intra-seasonal time scale. Based on the OLR pentad index, spatial composites of
HORIZONTAL WIND FIELD AT 200hPa P-2 (SW)

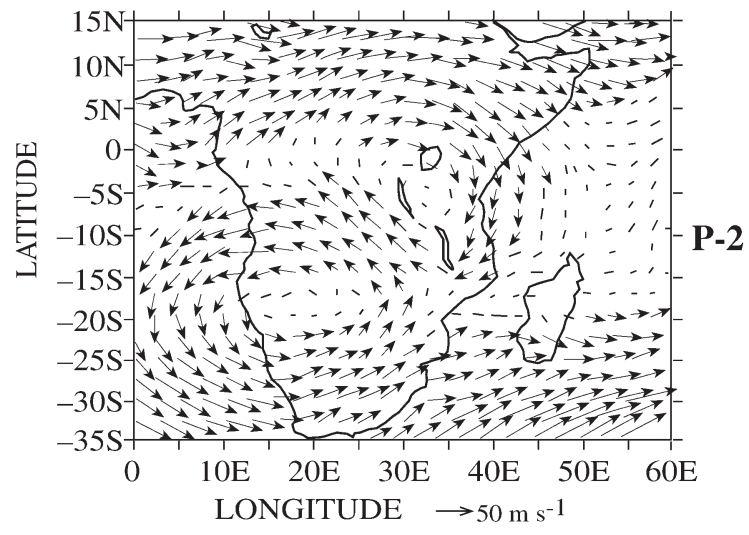

HORIZONTAL WIND FIELD AT 200hPa P-1 (SW)

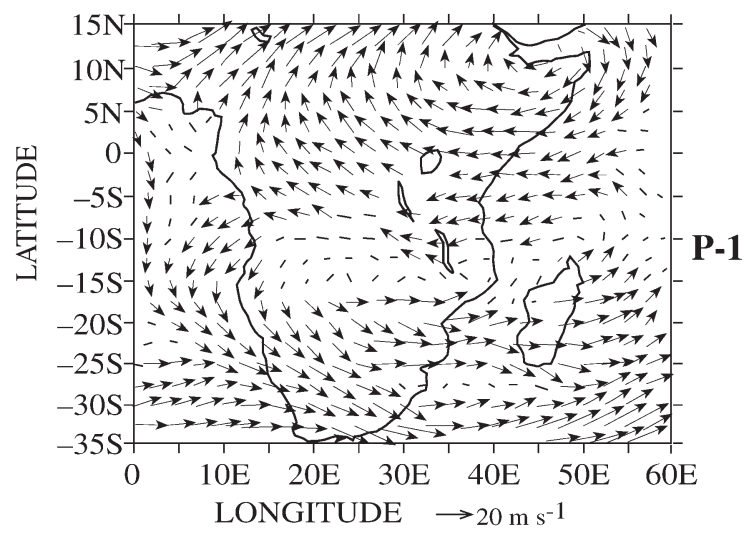

HORIZONTAL WIND FIELD AT 200hPa P0 (SW)

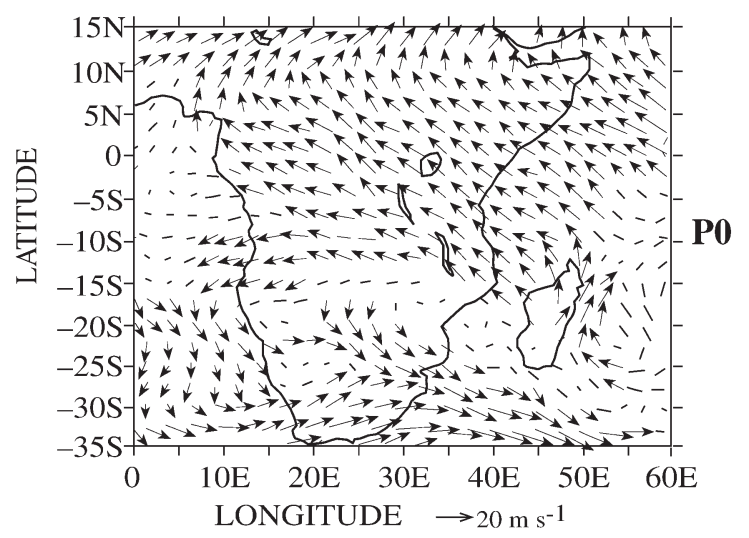

Fig. 10. Case study map sequence (as in Fig. 8) for $200 \mathrm{hPa}$ winds. Length of arrow indicates amplitude according to key

kinematic and thermodynamic fields for the onset of convection and the most active phase were analysed. Time-longitude Hovmoller plots of filtered anomalies of OLR and zonal winds at $850 \mathrm{hPa}$ level in the 7.5 to $10^{\circ} \mathrm{S}$ latitude band revealed the propagating nature 
Fig. 11. Schematic diagram illustrating environmental factors modulating the strength of transient $\mathrm{MJO}$ in the African hemisphere. Shaded regions are mean surface temperatures $>27$ (darker) and $>28^{\circ} \mathrm{C}$; isolines indicate aspects of mean $700 \mathrm{hPa}$ zonal winds. The bold line indicates the 2000 m eastern African escarpment

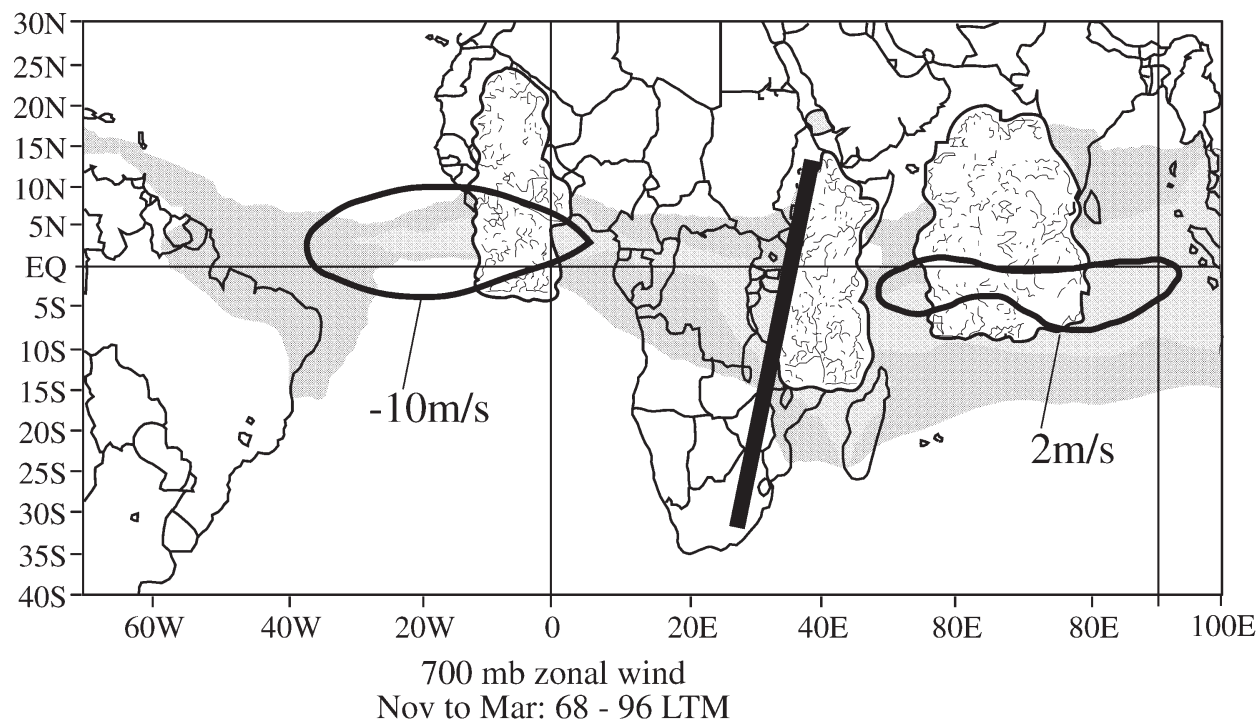

and coupling of local circulation and convection. The most dominant system was the eastward propagating MJO, whilst westward and quasi-stationary types also occurred.

Time series plots of a pentad OLR index demonstrated the existence of passive and active phases within the rainy season. Year-to-year variations in amplitude and periodicity of convection were noted. Spectral peaks with periods $>30 \mathrm{~d}$ could be linked to the $\mathrm{MJO}$ and those in the $20 \mathrm{~d}$ range are related to tropical and mid-latitude waves. In the case study the northeastward propagation of convection was linked with an eastward-moving sub-tropical trough. Composite convective events were associated with: an influx from the northeasterly monsoon over the Arabian Sea; an increase of upper westerlies over the tropical Atlantic, which bifurcate into the African subtropics; and development of lower westerlies over the Congo basin. Time-longitude diagrams revealed eastward-propagating and quasi-stationary features in the 7.5 to $10^{\circ} \mathrm{S}$ latitude band. Westward-propagating features were found to be generally weak and short-lived. The eastward-propagating convective systems are coupled with westerly winds at the $850 \mathrm{hPa}$ level and upper easterlies over the west Indian Ocean moving at 2 to $8 \mathrm{~m} \mathrm{~s}^{-1}$. Large-scale, high amplitude events occurred at near-monthly intervals in most years.

Many intra-seasonal convective systems pass across the continent of Africa with small amplitude and propagate eastward into the Indian Ocean with increasing amplitude, as indicated schematically in Fig. 11. The ISO are better organised in warm ENSO years, coincident with upper westerlies over the Atlantic, and a longer zonal fetch of $\mathrm{SST}>28^{\circ} \mathrm{C}$ over the Indian Ocean. Many ISO exhibit MJO-like characteristics. Stronger equatorial convection and MJO activity favours rainy conditions over east Africa and the adjacent west Indian Ocean, yet drier weather over much of sub-tropical Africa. Although our investigation has identified interactions between transient waves and the background flow, further work is needed on how the ocean monsoons couple with circulation systems over Africa to 'pulse' the global ENSO signal.

\section{LITERATURE CITED}

Asnani GC (1993) Tropical meteorology. Noble Printers, Pune Chang CP (1977) Some theoretical problems of planetary scale monsoons. Pure Appl Geophys 115:1089-1109

Chen T, Tzeng R (1990) Global scale intra-seasonal and annual variation of divergent-water vapour flux. Meteor Atmos Phys 44:133-151

Hendon HH, Liebmann G (1990) The intra-seasonal (30-50) oscillation of the Australian summer monsoon. J Atmos Sci 47(24):2904-2923

Knutson TR, Weickmann KM (1987) 30-60 day atmospheric circulations: composite life cycles of convection and circulation anomalies. Mon Weather Rev 115:1407-1436

Krishnamurti TN, Jayakumar PK, Sheng J, Surgi N, Kumar A (1985) Divergent circulations on the 30-50 day time scale. J Atmos Sci 42:364-375

Lau KM, Peng L (1987) Origin of low frequency (intra-seasonal) oscillations in the tropical atmosphere. Part I: Basic theory. J Atmos Sci 44(6):950-972

Levey KM (1993) Intra-seasonal oscillations of convection over southern Africa. MSc thesis, University of Cape Town

Lorenc AC (1984) The evolution of planetary scale divergence during the FGGE year. Q J R Meteorol Soc 110:427-444

Madden RA (1986) Seasonal variation of the 40-50 day oscillation in the tropics. J Atmos Sci 43:3138-3158

Madden RA (1994) Observations of the 40-50 day tropical oscillations - a review. Mon Weather Rev 122:814-837

Madden RA, Julian PR (1971) Detection of a 40-50 day oscillation in the zonal wind in the tropical Pacific. J Atmos Sci 28:702-708

Madden RA, Julian PR (1972) Description of global-scale circulation cells in the tropics with 40-50 day period. 
J Atmos Sci 29:1109-1123

Makarau A (1994) Intra-seasonal oscillatory modes of the southern Africa summer circulation. PhD thesis, University of Cape Town

Mpeta EJ (1997) Intra-seasonal convection dynamics over southwest and northeast Tanzania: an observational study. MSc thesis, University of Cape Town

Murakami T, Nakazawa T (1985) Tropical 45-day oscillations during the 1979 Northern Hemisphere summer. J Atmos Sci 42:1107-1122

Murakami T, Long-Xun C, Xie AN, Shretha ML (1986) Eastward propagation of 30-60 day perturbations as revealed from outgoing longwave radiation data. J Atmos Sci 43(10):961-971

Mutai CC, Ward MN (1998) Predictability of the East African short rains on intraseasonal to interannual timescales. Proc 23rd Annual Climate Diagnostics Workshop, Miami, Florida, Oct 26-30. NOAA, Washington, DC

Rui H, Wang B (1990) Development characteristics and dynamic structure of tropical intra-seasonal convection anomalies. J Atmos Sci 47:357-379

Editorial responsibility: Hans von Storch, Geesthacht, Germany
Semazzi HFM (1980) Stationary barotropic flow induced by a mountain over a tropical belt. Mon Weather Rev 108: 922-930

Steiner EJ (1989) Moisture convergence during a convergence flare up in the tropics. Proc 4th Conference on Satellite Meteorology and Oceanography. AMS, Boston, p $154-157$

Vincent DG, Sperling Z, Fink A, Zube S. Speth P (1991) Intraseasonal oscillation of convective activity in the tropical southern hemisphere: May, 1984-April, 1986. J Clim 4: $40-53$

Wang B, Rui H (1990) Synoptic climatology of transient tropical intra-seasonal convectional anomalies: 1975-1985. Meteorol Atmos Phys 44:43-61

Weickmann KM, Khalsa SJ (1990) The shift of convection from the Indian ocean to the western Pacific Ocean during a 30-60 day oscillation. Mon Weather Rev 118:964-978

Weickmann KM, Lussky GR, Kutzbach JE (1985) Intra-seasonal (30-60 day) fluctuations of outgoing longwave radiation and $250 \mathrm{mb}$ stream function during northern winter. Mon Weather Rev 113:941-961

Submitted: February 16, 2000; Accepted: October 8, 2000 Proofs received from author(s): June 18, 2001 